\title{
Expression of apoptosis in human saphenous vein grafts in restoration of blood flow through
} coronary bypass surgery

\author{
Expressão da apoptose em enxertos de veias safenas humana para restauração do fluxo sanguíneo \\ coronariano por derivação
}

Luís Fernando TIRAPELLI ${ }^{1}$, Daniela Pretti da Cunha TIRAPELLI ${ }^{2}$, Marcelo Bellini DALIO³ ${ }^{3}$ Alfredo José RODRIGUES ${ }^{4}$, Paulo Roberto Barbosa ÉVORA ${ }^{5}$

RBCCV 44205-1094

\section{Resumo}

Objetivo: Investigar o possível papel da apoptose em distensões breves de veias safenas humanas em diferentes pressões.

Métodos: Segmentos frescos isolados de veia safena humana foram distribuídos em 4 grupos: controle ou distendidos (D) por quinze segundos a 100, 200 e $300 \mathrm{mmHg}$. O grau de apoptose das caspases $3,8,9$ e expressão da proteína anti-apoptótica Bcl-2 foram avaliados por imuno-histoquímica.

Resultados: Segmentos frescos distendidos isolados de veias safenas humanas apresentaram expressão protéica para apoptose similar às veias controle. No entanto, a expressão de Bcl-2 foi significativamente maior nos segmentos distendidos a $300 \mathrm{mmHg}$, quando comparados à veia controle.

Conclusão: Estes achados demonstram que segmentos intactos de veias safenas humanas submetidos a distensões em diferentes pressões têm expressão de proteínas apoptóticas similares quando comparados com veias controle nãodistendidas. Por conseguinte, breves distensões comumente realizadas durante a coleta cirúrgica não ativam o processo de apoptose e, provavelmente, não estão envolvidas em mecanismos fisiopatológicos que levam à falência do enxerto.

Descritores: Apoptose. Procedimentos cirúrgicos cardíacos. Veia safena.
1. PhD Professor (Professor FMRP - USP)

2. $\mathrm{PhD}$ (Researcher FMRP - USP)

3. Master's Degree (PhD Student FMRP - USP)

4. $\mathrm{PhD}$ (Professor FMRP - USP)

5. Titular Professor (Professor FMRP - USP)
Abstract

Objective: To investigate the possible role of apoptosis on brief distensions of human saphenous veins at different pressures.

Methods: Fresh isolated grafts of human saphenous vein were assigned as control or distended (D) for fifteen seconds at 100, 200 and $300 \mathrm{mmHg}$. The degree of apoptotic caspases 3, 8, 9 and anti-apoptotic protein Bcl-2 expression were assessed by immunohistochemistry.

Results: Fresh isolated segments of distended human saphenous veins presented similar apoptotic protein expression when compared with control veins. However, the Bcl-2 expression was significantly higher in the $300 \mathrm{mmHg}$ distended segments compared with the control vein.

Conclusion: These findings show that intact segments of human saphenous veins submitted to distensions at different pressures have similar apoptotic proteins expression when compared with non-distended control veins. Therefore, brief distensions commonly performed during surgical harvesting do not trigger apoptosis, and probably are not involved on the physiopathological mechanisms that lead to graft failure.

Descriptors: Apoptosis. Cardiac surgical procedures. Saphenous vein. 


\section{INTRODUCTION}

Although widely used as vascular conduit in coronary and peripheral revascularization surgery, saphenous vein grafts have shorter patency than arterial ones. One possible explanation for this fact is that exposition of saphenous vein to high pressures induces functional and morphological alterations that can trigger physiopathological mechanism, which lead to early thrombosis and graft failure. During harvesting, saphenous vein is exposed to various degrees of distention, being sometimes very high [1].

Apoptosis is one described mechanism in failing saphenous vein graft physiopathogy. It is involved in intimal layer modification with muscular layer thickening through fibrous transformations [2]. In addition, previous studies investigated the role of apoptosis in early saphenous vein primary varices. Thus, pressure distensions and apoptosis may have clinical and experimental implications in endothelial function and, by consequence, in the use of the saphenous vein as arterial graft [3].

The aim of this study was to quantify expression of pro and anti-apoptotic proteins in human saphenous veins after brief distensions at different pressures. Hence, it can be speculated if these distensions, which are commonly performed during surgical harvesting, have a role, through apoptosis, in saphenous vein graft failure.

\section{METHODS}

\section{Harvesting of human tissue}

Human saphenous vein segments were harvested from 20 patients undergoing coronary artery bypass surgery. Unused segments at the distal end were taken for study. After their removal, segments were immediately placed in normothermic and oxygenated Krebs solution with the following composition: $\mathrm{NaCl} 118 \mathrm{mmol} / \mathrm{L}, \mathrm{KCl} 4.7 \mathrm{mmol} / \mathrm{L}$, $\mathrm{KH}_{2} \mathrm{PO}_{4} 1.2 \mathrm{mmol} / \mathrm{L}, \mathrm{MgSO}_{4} 7 \mathrm{H}_{2} \mathrm{O} 1.17 \mathrm{mmol} / \mathrm{L}, \mathrm{CaCl}_{2} 2 \mathrm{H}_{2} \mathrm{O}$ $2.5 \mathrm{mmol} / \mathrm{L}, \mathrm{NaHCO}_{3} 25 \mathrm{mmol} / \mathrm{L}$ and glucose $5.6 \mathrm{mmol} / \mathrm{L}$.

The time between excision of tissue in the operating room and vein distensions in the laboratory was less than 15 minutes. Vein segments were carefully cleaned of fat and loose connective tissue and cut into rings for each experimental group ( $4 \mathrm{~mm}$ in length). No distensions were performed in veins in any moment of harvesting. Veins with macroscopic evidences of varicosities were excluded.

All procedures were reviewed and approved by the local Research Ethics Committee.

\section{Vein distension technique}

For standardization of distention pressures, each vein segment was connected to a three-way stopcock as previously published $[1,4]$. The other ways were connected to a mercury manometer and to an angioplasty balloon insufflator. The insufflator used allowed obtaining and maintaining uniform distension pressures. As its built-in manometer had scales in ATM and PSI, a mercury column manometer was used to measure the experimental pressures in $\mathrm{mmHg}(100,200$ and $300 \mathrm{mmHg})$. For performing distensions, vein segment was occluded at the level of its free extremity. A single researcher, who codified the samples for posterior blind analysis, carried all maneuvers.

\section{Experimental groups}

Four experimental groups were designed: Group 1: Control; Group II: Distention with Krebs solution to 100 mmHg for 15 seconds; Group III: Distention with Krebs solution $200 \mathrm{mmHg}$ for 15 seconds and; Group IV: Distention with Krebs solution to $300 \mathrm{mmHg}$ for 15 seconds.

\section{Human saphenous vein immunohistochemistry}

After dilatation, vein segments were immediately removed and fixed in $10 \%$ for $24 \mathrm{~h}$. Longitudinal sections (3 $\mu \mathrm{m}$ ) of segments were incubated in $3 \% \mathrm{H}_{2} \mathrm{O}_{2}$ and Pierce solution to block endogenous peroxidase and biotin, respectively. Sections were subsequently incubated with primary antibodies against pro-apoptotic proteins: caspase 3 (1:200 dilution-CPP32, Novacastra $\left.{ }^{\circledR}\right)$, caspase 8 (1:100 dilution- NCL-CASP-8, Novacastra $\left.{ }^{\circledR}\right)$ and caspase 9 (1:100 dilution- NCL-CASP-9, Novacastra $\left.{ }^{\circledR}\right)$; and against antiapoptotic protein Bcl-2 (1:200 dilution-NCL-bcl-2-486, Novacastra $\left.{ }^{\circledR}\right)$. Secondary antibodies biotin-conjugated secondary anti-rabbit antibody (1:1000; Vector Laboratories Inc., Burlingame, CA) and streptavidin-conjugated peroxidase (Vecstatin Abc kit, Vector Laboratories Inc.) were also incubated. Color was developed by the addition of DAB (Sigma Chemical, St. Louis, MO). Counting of positive marked cells for caspases 3, 8, 9 and Bcl-2 were measured by using a photo camera (Axio Cam, Zeiss, Germany) and the software Axiovision 4.6 (Zeiss, Germany).

For quantifying apoptosis, immunohistochemical expression of pro and anti-apoptotic proteins was determined according to the intensity of cytoplasmic and nuclear staining. Caspases 3, 8, 9 and Bcl-2 immunoreactive cells were counted manually at $400 x$ magnification. In each sample, three fields with greatest concentration of marked cell were selected (areas of "hot spots"). In each field, the percentage rate of counted marked cells in a total of approximately 600 cells was calculated and immunohistochemical expression was graduated according to the following classification: 0 (zero) no mark, (+) up to $25 \%$ marked cells (low expression), $(++)$ from $25 \%$ to $50 \%$ marked cells (intermediate expression); $(+++)$ from $50 \%$ to $75 \%$ marked cells (high expression); and $(++++$ ) over $75 \%$ of cells marked (very high expression).

All results are expressed as mean \pm SEM. Analysis of Variance One-way and Bonferroni's $t$ tests were used for 
data analysis. Values were considered to be statistically significant when $\mathrm{P}$ was less than 0.05 . Statistical analyses were performed with Graph Pad Prism 4.0 (Graph Pad Software Inc., San Diego, CA).

\section{RESULTS}

Positive immunohistochemical marked cells were observed in muscular layer and primarily in adventitial layer.

Caspase 3 detection. The degree of immunohistochemical expression for caspase 3, an apoptotic promoter, presented no difference between distended vein segments at 100, 200 and $300 \mathrm{mmHg}$ (zero [0] and low expression [+]) when compared to control vein (zero [0] and low expression [+]) (Figure 1).

Caspase 8 detection. For caspase 8, also an apoptotic promoter, no difference in the degree of immunohistochemical expression was found in segments of vein submitted for
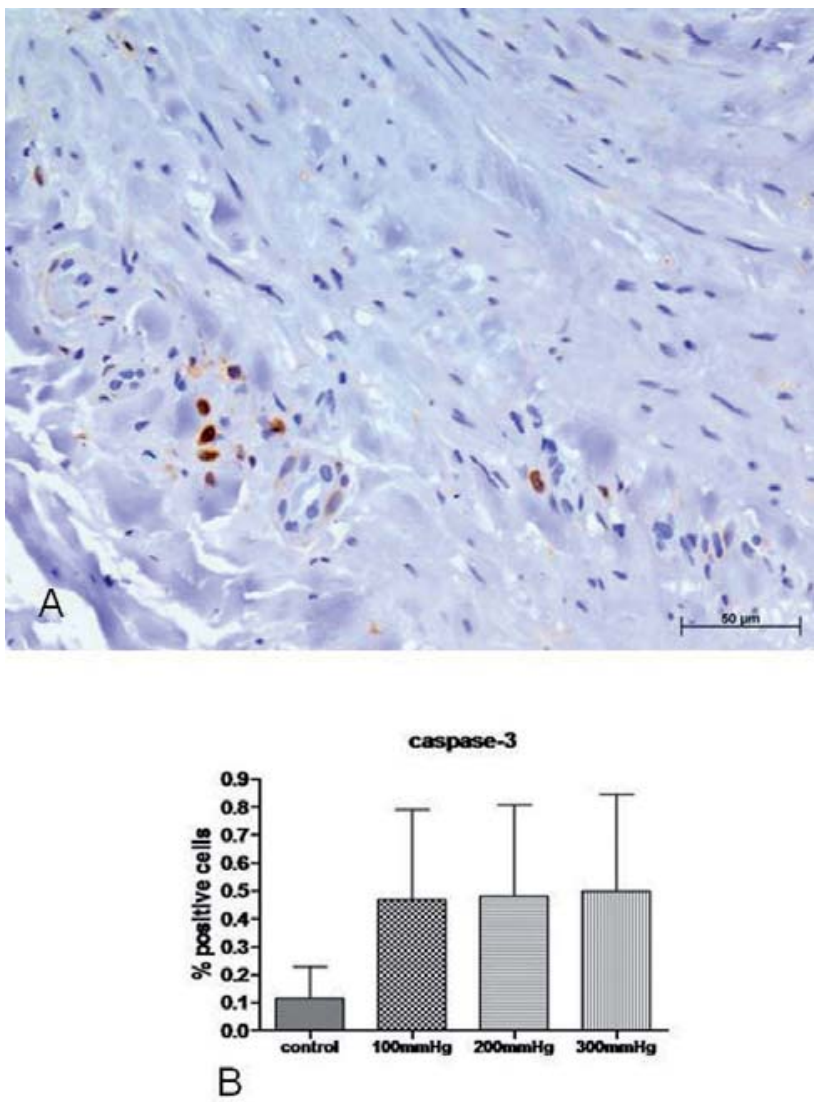

Fig. 1 - Representative photomicrograph of immunohistochemical analysis for expression of caspase 3 in segments of vein submitted for fifteen seconds at $300 \mathrm{mmHg}(\mathrm{A})$ : original magnification 400X. (B) The numbers (mean, SD) of the caspase 3 positive cells of approximately 600 cells in control and segments of the vein submitted for fifteen seconds at 100, 200 and $300 \mathrm{mmHg}$ fifteen seconds at 100, 200 and $300 \mathrm{mmHg}$ (zero [0] and low expression [+]) when compared to control vein (zero [0] and low expression [+]) (Figure 2).

Caspase 9 detection. Again, the degree of immunohistochemical expression for caspase 9 , an apoptotic promoter, showed also no difference between distended segments of vein submitted for fifteen seconds at 100, 200 and $300 \mathrm{mmHg}$ (zero [0] and low expression [+]) when compared to control vein (zero [0] and low expression [+]) (Figure 3).

Bcl-2 detection. For Bcl-2, an apoptotic suppressor, the degree of immunohistochemical expression differed significantly in the distended segments of vein submitted for fifteen seconds at $300 \mathrm{mmHg}$ (low expression [+] and intermediate expression $[++]$ ) when compared to control vein (low expression $[+]$ and intermediate expression $[++]$ ) (Figure 4).
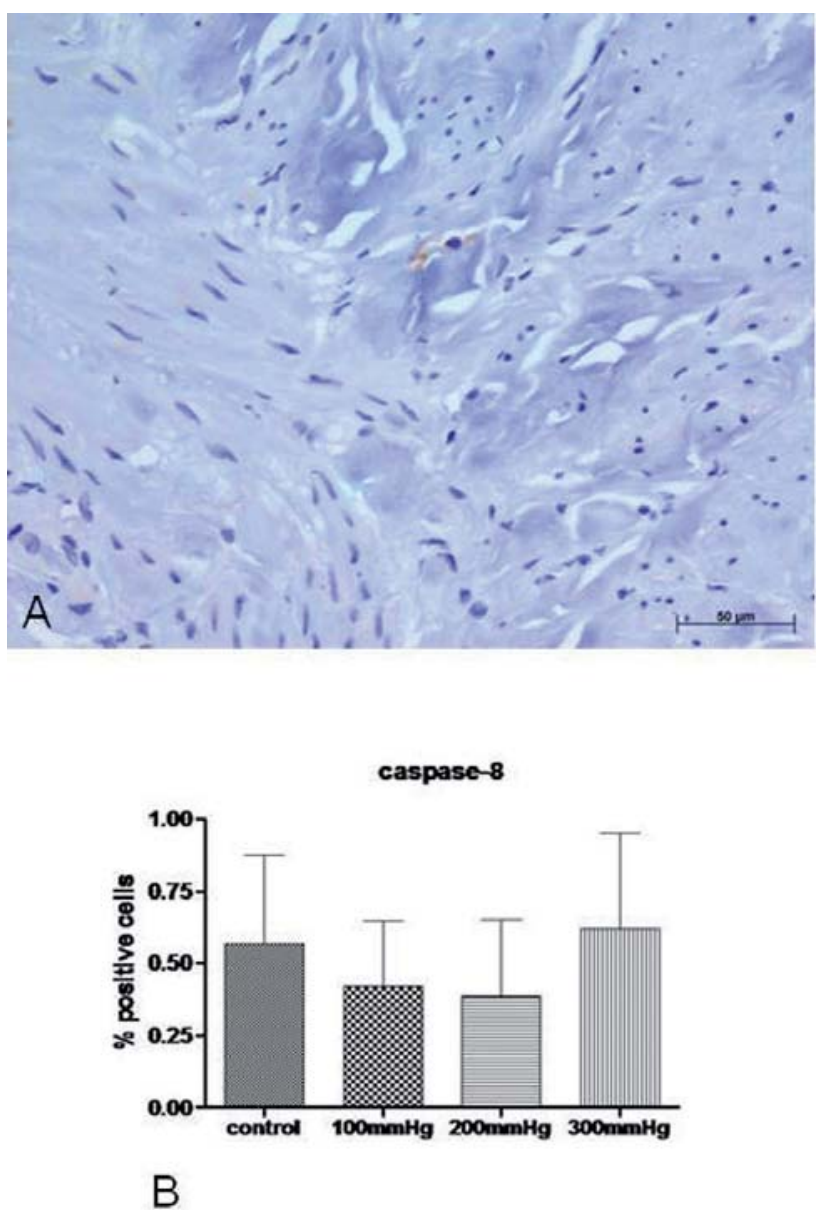

Fig. 2 - Representative photomicrograph of immunohistochemical analysis for expression of caspase 8 in segments of vein submitted for fifteen seconds at $300 \mathrm{mmHg}(\mathrm{A})$ : original magnification 400X. (B) The numbers (mean, SD) of the caspase 8 positive cells of approximately 600 cells in control and segments of the vein submitted for fifteen seconds at 100, 200 and $300 \mathrm{~mm} \mathrm{Hg}$ 

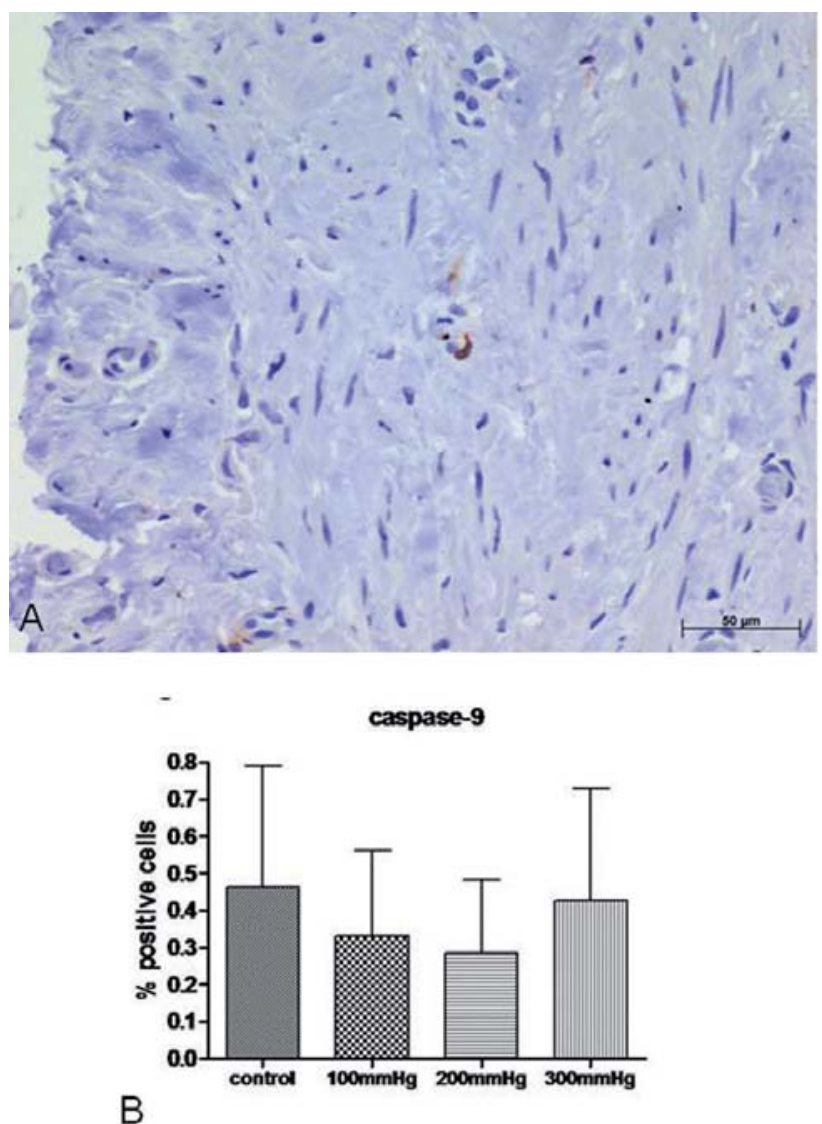

Fig. 3 - Representative photomicrograph of immunohistochemical analysis for expression of caspase 9 in segments of vein submitted for fifteen seconds at $300 \mathrm{mmHg}$ (A): original magnification 400X. (B) The numbers (mean, SD) of the caspase 9 positive cells of approximately 600 cells in control and segments of the vein submitted for fifteen seconds at 100, 200 and $300 \mathrm{mmHg}$

\section{DISCUSSION}

The results of this study reveal that fresh isolated segments of saphenous veins submitted to distension at 100 to $300 \mathrm{mmHg}$ for fifteen seconds, presented similar expression of pro-apoptotic proteins when compared with control. However, the anti-apoptotic Bcl-2 expression was significantly higher in the $300 \mathrm{mmHg}$-distended veins when compared with control. Positive immunohistochemical stained cells were observed in muscular layer and primarily in adventitial layer.

Apoptosis is defined as active physiological and genetically controlled process of cell suicide that carries an important function in the development and homeostasis of multicellular organisms $[2,5,6]$. The pathways involved in its induction in human saphenous vein graft are still unclear. This process had been associated to autologus
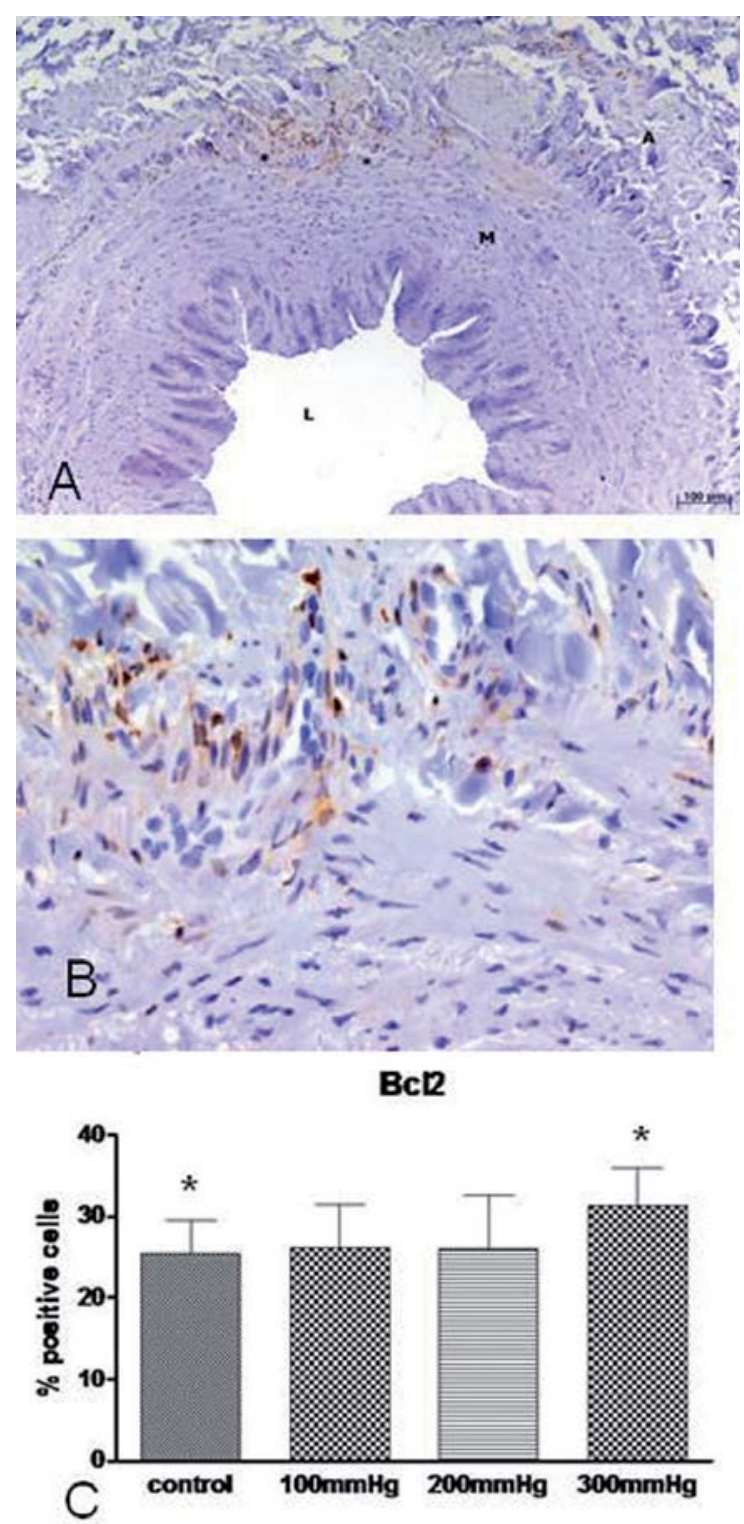

Fig. 4 - Representative photomicrographs of immunohistochemical analysis for expression of Bcl-2 in segments of vein submitted for fifteen seconds at $300 \mathrm{mmHg}$ (A): original magnification 100X; (B): original magnification 400X. Adventitial layer (A), lumen $(L)$ and muscular layer $(M)$. An asterisk $(*)$ indicates places with the highest positive mark. (C) The numbers (mean, $S D$ ) of the Bcl-2 positive cells of approximately 600 cells in control and segments of the vein submitted for fifteen seconds at 100, 200 and $300 \mathrm{mmHg}$

saphenous vein grafts pathobiology, where it is supposed to be involved on modifications of its intimal layer with thickening of its muscular layer through fibrous transformations $[5,6]$ Two pathways, intrinsic and extrinsic, mediate the apoptotic response, depending on the origin of the death stimulus. The intrinsic pathway (mitochondrial) 
results from cytochrome $\mathrm{C}$ release from mitochondria to cytosol, which combines with Apaf-1 (pro-apoptotic factor) in presence of dATP or ATP with consequent formation of an oligomeric compound referred to as "apoptossome", which recruits and activates caspase-9, allowing activation of caspases effectors such as caspase-3 [7]. The extrinsic pathway, which is originated from external stimulus, can be converted to intrinsic through caspase-8, that cleaves protein Bid, which promotes membrane proteins release [8]. As the immunohystochemial caspases expression was not affected by the saphenous vein distensions, it is possible to conclude that the two apoptosis pathways were not impaired.

In our study, the ratio of anti-apoptotic Bcl-2 expression differed significantly in segments distended for fifteen seconds at $300 \mathrm{mmHg}$ when compared to control. However, proteins associated to apoptosis have been identified in saphenous veins coronary grafts by immunohistochemistry, using the antibodies Bcl-2, Fas, Bax, p53 and CPP32, and by TUNEL nuclear fragmentation technology. Many studies observed different patterns of cell death in atherosclerotic and non-atherosclerotic areas of saphenous vein grafts intimal layer. In atherosclerotic areas, pro-apoptotic proteins were widely expressed, but ultra structural analysis was unable to identify cells with apoptotic characteristics. Necrotic cells have, frequently, negative correlation with TUNEL Bcl-2 expression. Moreover, in non-atherosclerotic areas, expression of both antiapoptotic proteins (Bcl-2) as other pro-apoptotic biomarkers (Bax, p53 and CPP32) had correlation with TUNEL. With ultra structural analysis, apoptotic bodies and necrosis were observed in non-atherosclerotic areas of saphenous vein grafts. These observations indicate that in atherosclerotic areas, cell death occurs mainly by necrosis, while in non-atherosclerotic areas, it occurs either by necrosis or apoptosis $[9,10]$. Based on these data it is possible to speculate that high $(300 \mathrm{mmHg})$ brief distensions (15 seconds) would be associated with failure mechanisms in non-atherosclerotic coronary saphenous vein grafts.

There is one last comment that is mandatory concerning pressure induced saphenous vein apoptosis. Many studies compared varicose and healthy saphenous veins, analysing histological changes and immunohistochemical expression of caspase- 9 and Bax, two mediators that regulate apoptotic intrinsic mitochondrial pathway. Samples of varicose veins presented a more disorganized architecture compared to normal veins. In addition, they presented healthy increase of collagen fibers and decrease in density and size of elastic fibers. The immunoreactivity to caspase- 9 and Bax in muscular layer cells was significantly smaller in varicose veins when compared to healthy ones, demonstrating a low apoptotic regulation [11]. Beside these concepts about chronic varicose veins, one well carried out study showed that two-minute distensions of $300 \mathrm{mmHg}$ in intact human saphenous veins induced p38 activation, which is associated with apoptosis [6]. As our model adopted 15-second distension time, it is possible to speculate that pressure induced apoptosis is time-dependent.

MAPKs (mitogen-activated protein kinases) are activated in response to a wide variety of extracellular stimuli. The JNK and p38 MAPK signaling cascades are activated in response to cellular stress and certain cytokines via the activation of $G$ protein coupled receptors and are known to be involved in apoptosis [6]. Cornelissen et al. [6] demonstrated that mechanical stretch caused by pressure distension of intact human saphenous vein (SV) induces the activation of p38 maintained for 3 and 6 hours after harvesting, being significantly higher at 24 hours compared with control vein, and this is associated with apoptosis (co-localization of phosphorylated p38 and apoptosis by immunohistochemistry). Furthermore, inhibition of p38 kinase activity in human SV vascular smooth muscle cells and distended segments reduced apoptosis.

Despite the use of that method in the collection of the grafts of saphenous veins, our findings are contradictory to those described by Cornelissen et al. [6], possibly because after pressure distention of the venous segments, the mechanism of apoptosis was assessed immediately after collection. These findings demonstrate that intact segments of the human saphenous vein submitted to different brief (15 seconds) crescent pressures (100, 200 and $300 \mathrm{mmHg}$ ) have similar apoptotic proteins expression when compared with non-distended control veins. The brief distensions commonly performed during surgical harvesting, do not trigger immediate apoptosis, but the deposition of extracellular matrix and a progressive increase in intimal fibrosis and a reduction in cellularity observed in late SV grafts is in agreement with the incidence of apoptosis as an early event in SV grafts [12], suggesting that cell death by apoptosis could be the etiological factor in failure of grafts.

The findings of these studies suggest that the early stages of SV bypass grafting may have important longterm consequences.

\section{ACKNOWLEDGMENTS}

This study was supported in part by FAPESP - Fundação de Amparo à Pesquisa do Estado de São Paulo, SP, Brazil and FAEPA - Fundação de Apoio ao Ensino, Pesquisa e Assistência do Hospital das Clínicas da Faculdade de Medicina de Ribeirão Preto da Universidade de São Paulo. 


\section{REFERENCES}

1. Tineli RA, Viaro F, Dalio MB, Reis GS, Basseto S, Vicente WV, et al. Mechanical forces and human saphenous veins: coronary artery bypass graft implications. Rev Bras Cir Cardiovasc. 2007;22(1):87-95.

2. Kockx MM, Cambier BA, Bortier HE, De Meyer GR, Declercq SC, van Cauwelaert PA, et al. Foam cell replication and smooth muscle cell apoptosis in human saphenous vein grafts. Histopathology. 1994;25(4):365-71.

3. Urbanek T, Skop B, Wiaderkiewicz R, Wilczok T, Ziaja K, Lebda-Wyborny $\mathrm{T}$, et al. Smooth muscle cell apoptosis in primary varicose veins. Eur J Vasc Endovasc Surg. 2004;28(6):600-11.

4. Viaro F, Carlotti CG Jr, Rodrigues AJ, Vicente WV, Bassetto S, Reis GS, et al. Endothelium dysfunction caused by acute pressure distension of human saphenous vein used for myocardial revascularization. Rev Bras Cir Cardiovasc. 2007;22(2):169-75.

5. Galea J, Armstrong J, Francis SE, Cooper G, Crossman DC, Holt CM. Alterations in c-fos expression, cell proliferation and apoptosis in pressure distended human saphenous vein. Cardiovasc Res. 1999;44(2):436-48.

6. Cornelissen J, Armstrong J, Holt CM. Mechanical stretch induces phosphorylation of p38-MAPK and apoptosis in human saphenous vein. Arterioscler Thromb Vasc Biol. 2004;24(3):451-6.

7. Salvesen GS, Duckett CS. IAP proteins: blocking the road to death’s door. Nat Rev Mol Cell Biol. 2002;3(6):401-10.

8. Riedl SJ, Shi Y. Molecular mechanisms of caspase regulation during apoptosis. Nat Rev Mol Cell Biol. 2004;5(11):897907.

9. Wang AY, Bobryshev YV, Liang H, Cherian SM, Inder SJ, Ashwell KW, et al. Electron-microscopic detection of apoptotic and necrotic cell death in non-atherosclerotic areas of stenotic aortocoronary saphenous vein bypass grafts. J Submicrosc Cytol Pathol. 2000;32(2):209-19.

10. Wang AY, Bobryshev YV, Cherian SM, Liang H, Tran D, Inder SJ, et al. Expression of apoptosis-related proteins and structural features of cell death in explanted aortocoronary saphenous vein bypass grafts. Cardiovasc Surg. 2001;9(4):319-28.

11. Ducasse E, Giannakakis K, Chevalier J, Dasnoy D, Puppinck P, Speziale, et al. Dysregulated apoptosis in primary varicose veins. Eur J Vasc Endovasc Surg. 2005;29(3):316-23.

12. Francis SE, Hunter S, Holt CM, Gadsdon PA, Rogers S, Duff $\mathrm{GW}$, et al. Release of platelet-derived growth factor activity from pig venous arterial grafts. J Thorac Cardiovasc Surg. 1994;108(3):540-8. 